\title{
Effect of chromium supplementation on chromium status, insulin and glucose level in Non-insulin Dependent Diabetes Mellitus (NIDDM) subjects
}

Murjiah Dinarto ${ }^{*}$, Arifin Suyardi ${ }^{*}$, Sarwono Waspadji ${ }^{\dagger}$

\begin{abstract}
Abstrak
Telah diteliti pengaruh pemberian kromium pikolinat terhadap status kromium tubuh, insulin serum serta glukosa darah pada 20 pasien DMTTI. Subyek dibagi menjadi kelompok perlakuan dan kelompok kontrol masing-masing 10 pasien. Sejumlah 3 pasien gagal menyelesaikan penelitian sehingga jumlah akhir menjadi 17 pasien. Didapatkan nilai median kromium serum $0,09 \mu g / L$ dengan rentangan 0,01-0,48 $\mu \mathrm{g} / \mathrm{L}$. Tidak didapatkan perbedaan bermakna untuk status kromium tubuh yang dinyatakan sebagai respons relatif kromium, insulin serum maupun glukosa darah antara kedua kelompok setelah pemberian kromium pikolinat 500 ug/hari selama 4 minggu. Data ini menunjukkan bahwa secara statıstik belum tampak pengaruh kromium terhadap status kromium tubuh, insulin serum maupun glukosa darah pada pasien DMTTI.
\end{abstract}

\begin{abstract}
The effects of supplemental Cr picolinate on body Cr state, serum insulin and blood sugar in 20 NIDDM subjects was studied. Subjects were divided into a treatment and control group, 10 subjects for each group. Three subjects dropped out of the study. Median value of $\mathrm{Cr}$ serum was $0,09 \mu \mathrm{g} / \mathrm{L}$ with a range of $0,01-0,48 \mu \mathrm{g} / \mathrm{L}$. There was no significant difference for the body $\mathrm{Cr}$ state expressed as relative chromium response, serum insulin as well as blood sugar between the two groups after supplementation of $500 \mu \mathrm{g} / \mathrm{daily}$ of $\mathrm{C}_{r}$ picolinate for 4 weeks. These datas showed that the effect of $\mathrm{Cr}$ supplementation on body $\mathrm{Cr}$ state, serum insulin and blood sugar in NIDDM subjects was not statistically signiticant.
\end{abstract}

Keywords: glucose metabolism, insulin potentiator, diabetes mellitus control.

Chromium is an essential element in the metabolism of carbohydrate, fat and protein, acting as an insulin potentiator. $^{1-4}$ Daily Cr requirement differs according to age. In the adult it varies between 50-200 $\mu \mathrm{g} / \mathrm{daily},{ }^{5,6}$ and that amount might not always be present in the daily food consumed. Some factors might affect the biological activity of $\mathrm{Cr}$ in food sources i.e. whether it is in the organic or inorganic form the way food is prepared and menu composition. $7,8,9,10$

The WHO (1996) stated that the normal level of $\mathrm{Cr}$ serum is $0,14-0,15 \mu \mathrm{g} / \mathrm{L}$ whereas less than $0,14 \mu \mathrm{g} / \mathrm{L}$ is considered to be $\mathrm{Cr}$ deficient. ${ }^{10}$ Chromium deficiency in human is still hypothetical although some conditions such as glucose intolerance and increased insulin requirement could be stated as clinical manifestations of the condition. 11

\footnotetext{
${ }^{*}$ Department of Nutrition, Faculty of Medicine, University of Indonesia, Jakarta, Indonesia.

${ }^{\dagger}$ Department of Internal Medicine, Faculty of Medicine, University of Indonesia / Dr. Cipto Mangunkusumo National Central General Hospital, Jakarta, Indonesia.
}

In diabetic subjects the $\mathrm{Cr}$ serum level is $60 \%$ that of the normal subjects. ${ }^{12}$ Although there are still differences in results, some studies show the benefit of $\mathrm{Cr}$ supplementation in glucose intolerance ${ }^{13,14}$ and diabetes. ${ }^{15,16}$ The increase of diabetes prevalence after the age of $40^{17}$ and the physiological decrease in body $\mathrm{Cr}$ as an individual ages ${ }^{18}$ might perhaps be interlinked.

The aim of this study is to determine whether $\mathrm{Cr}$ supplementation affects the body $\mathrm{Cr}$ state, serum insulin and blood sugar control in NIDDM subjects.

\section{METHODS}

Twenty NIDDM subjects, 7 females and 13 males, aged between $40-65$ years, with body mass index of 21-25 (females) and 22,5-27 (males), fair and well controlled blood sugar levels ${ }^{19}$ participated in the study (Table 1).

After an initial stabilization period of 2 weeks, subjects were randomly divided into treatment and control group. With a single blind study design, the study was 
divided into two stages, with a washing period of two weeks in between (Figure 1). The stabilization period was to prepare subjects so that compliance on diet with or without oral hypoglycaemic medicine could be maintained throughout the study.

In the first four weeks (First stage) each subject was given a capsule of $\mathrm{Cr}$ picolinate $500 \mu \mathrm{g} /$ daily or placebo according to their group. After a two-week washing period, another four weeks (Second stage) with the same procedure was done after cross changing the groups.

On weeks 0, 4, 6 and 10 fasting and 1 hour serum $\mathrm{Cr}$, fasting and 2 hours serum insulin, blood sugar level (every 30 minutes for 2 hours) after 75 gram glucose loading were checked.

$\mathrm{Cr}$ serum levels were measured with the Neutron Activation Analysis method, ${ }^{20}$ serum insulin with the Radio Immunoassay method and blood sugar with the Glucose Oxydase Peroxydase method (Boehringer Mannheim).

$\mathrm{Cr}$ status was defined as a relative chromium response which is a ratio of 1 hour $\mathrm{Cr}$ level against fasting $\mathrm{Cr}$ level $^{21}$ and which till now could represent body $\mathrm{Cr}$ index..$^{10}$

Table 1. Basic variables characteristics treatment and control group

\begin{tabular}{|c|c|c|c|}
\hline Variables & $\begin{array}{c}\text { Treatment group } \\
\begin{array}{c}(\mathrm{n}=10) \\
\mathrm{X} \pm \mathrm{SD}\end{array}\end{array}$ & $\begin{array}{l}\text { Control group } \\
\qquad \begin{array}{c}(n=10) \\
X \pm S D\end{array}\end{array}$ & \\
\hline \multicolumn{4}{|l|}{ Age (Years) } \\
\hline Female & $56,5 \pm 8,3 \quad[4]^{*}$ & $54,7 \pm 9,6 \quad[3]^{*}$ & \\
\hline Male & $52,3 \pm 8,0 \quad[6]$ & $49,0 \pm 5,0 \quad[7]$ & \\
\hline Female + Male & $54,0 \pm 8,7 \quad[10]$ & $50,7 \pm 6,6 \quad[10]$ & NS \\
\hline \multicolumn{4}{|l|}{ Nutritional Status } \\
\hline Body Mass Index & $26,0 \pm 1,8$ & $25,1 \pm 1,6$ & NS \\
\hline \multicolumn{4}{|l|}{ Laboratory } \\
\hline SGPT & $18,1 \pm 4,7$ & $18,6 \pm 4,2$ & \\
\hline Creatinine & $0,9 \pm 0,1$ & $1,0 \pm 0,1$ & \\
\hline Albumin & $4,5 \pm 0,2$ & $4,6 \pm 0,2$ & NS \\
\hline HbA1C & $6,5 \pm 0,7$ & $6,7 \pm 0,8$ & NS \\
\hline \multicolumn{4}{|c|}{ Fasting Blood Sugar (Stabilization Period) } \\
\hline Early phase & $116,8 \pm 18,5$ & $111,7 \pm 13,5$ & NS \\
\hline & $98,9 \pm 33,4$ & $116,5 \pm 18,1$ & NS \\
\hline
\end{tabular}

Note $:$ NS $=$ Not significant

$$
*=n
$$

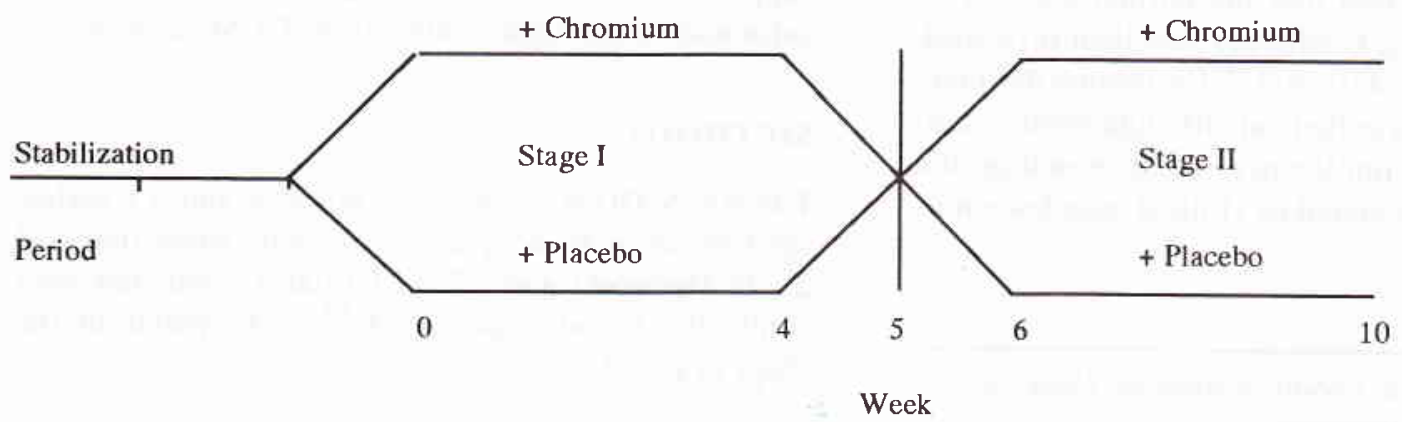

Figure 1. Study design 
Blood sugar control was expressed as " $\Delta$ area under the curve" which was the difference between area under the curve and fasting blood sugar area.

Diet stabilization compliance was established through quantitative food review at week 0 and 6 with the "two days recall" method, helped by using food models from the Nutrition Study and Development Centre, Bogor, Indonesia and a subsequent analysis with Indonap $2.0^{21}$ was used.

Statistical analysis was done at stage I, stage II and both stage I and II. Mean value and student T test were used for normal distribution, where as median value, Wilcoxon and Mann Whitney tests were used for abnormal distribution.

\section{RESULTS}

Chromium serum level for all subjects was $0,09 \mu \mathrm{g} / \mathrm{L}$ with a range of $0.01-0.48 \mu \mathrm{g} / \mathrm{L}$. There was no significant difference for the relative chromium response between the treated and control group in stage I and stage II.

Fasting and 2 hours serum insulin levels showed an increase for both groups (Table 2) followed directly by a decrease in stage II (Table 3) and with an increase again at stage I and II (Table 4). All the differences were not statistically significant.

Table 2. Effects of supplemental chromium on serum insulin and blood sugar at stage I

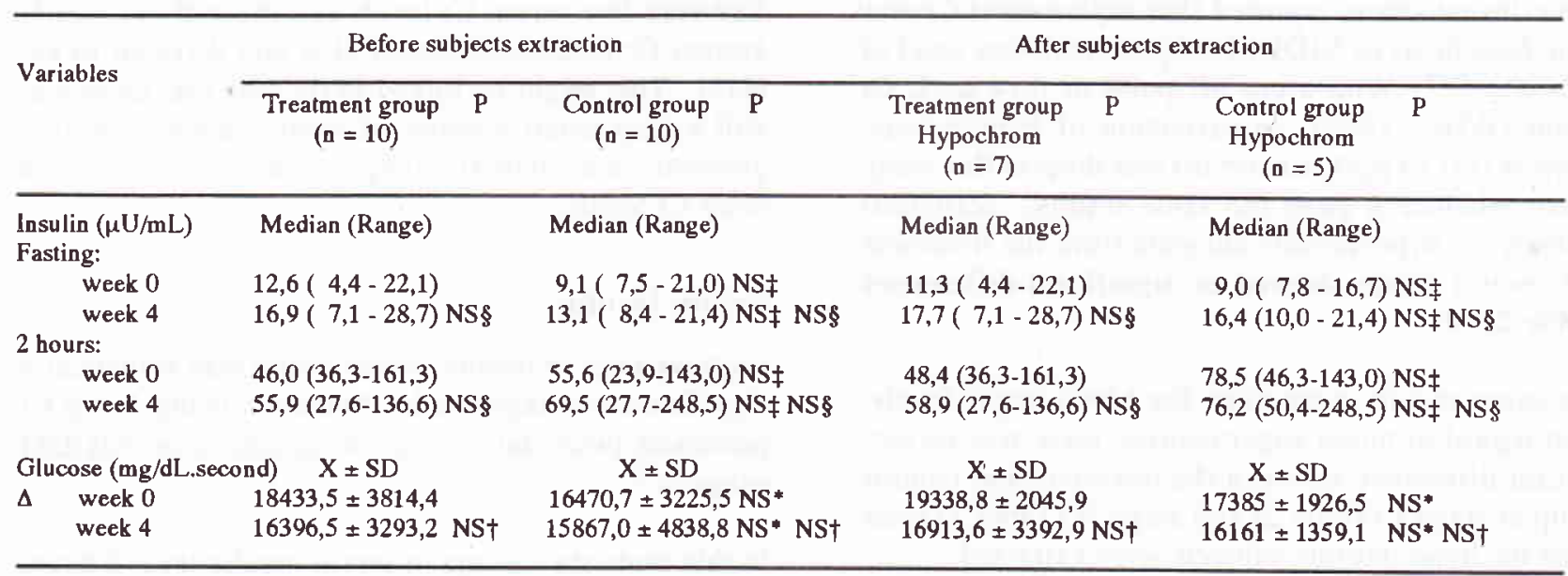

Note: NS : Not Șignificant $(p>0,05),{ }^{*}:$ Independent $t$ test, $\dagger:$ Dependent $t$ test, $¥:$ Mann Whitney test, $\$$ : Wilcoxon test

Table 3. Effects of supplemental chromium on serum insulin and blood sugar at stage II

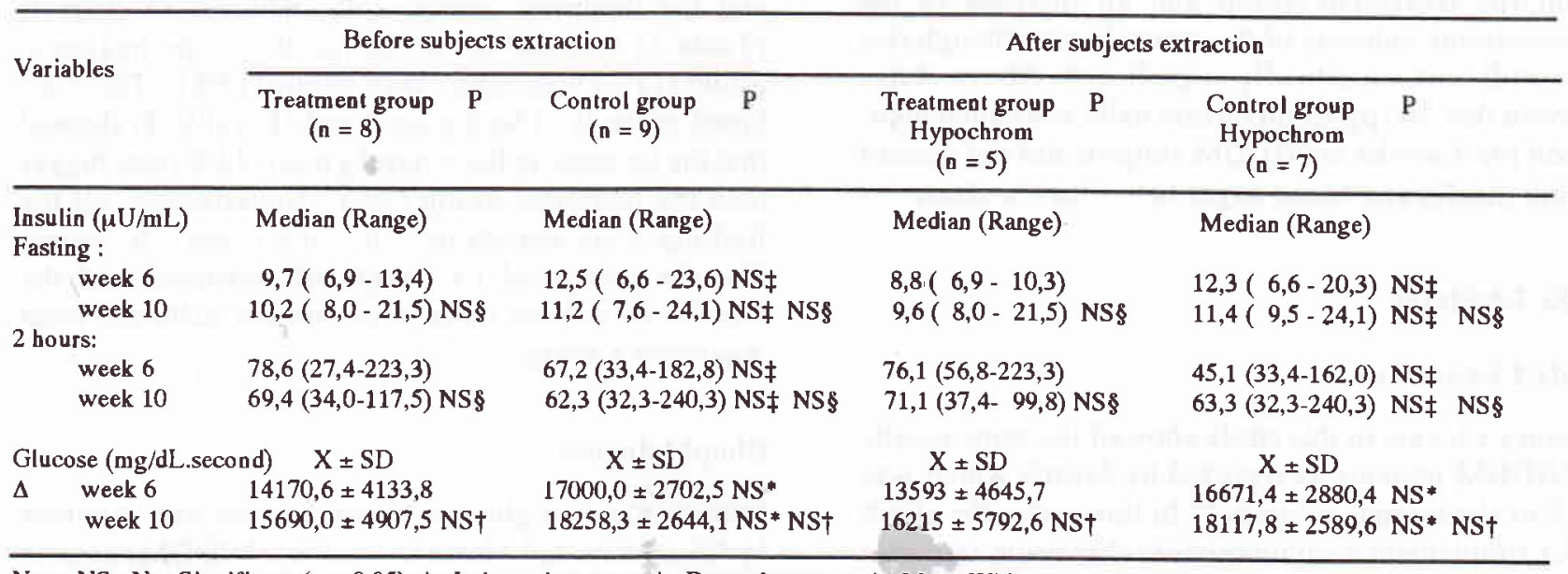

Note: NS : Not Significant ( $>0,05)$, : Independent $t$ test, $\dagger:$ Dependent $t$ test, $\ddagger$ : Mann Whitaey test, $\S:$ Wilcoxon test 
Table 4. Effects of supplemental chromium on serum insulin and blood sugar at stage I and II

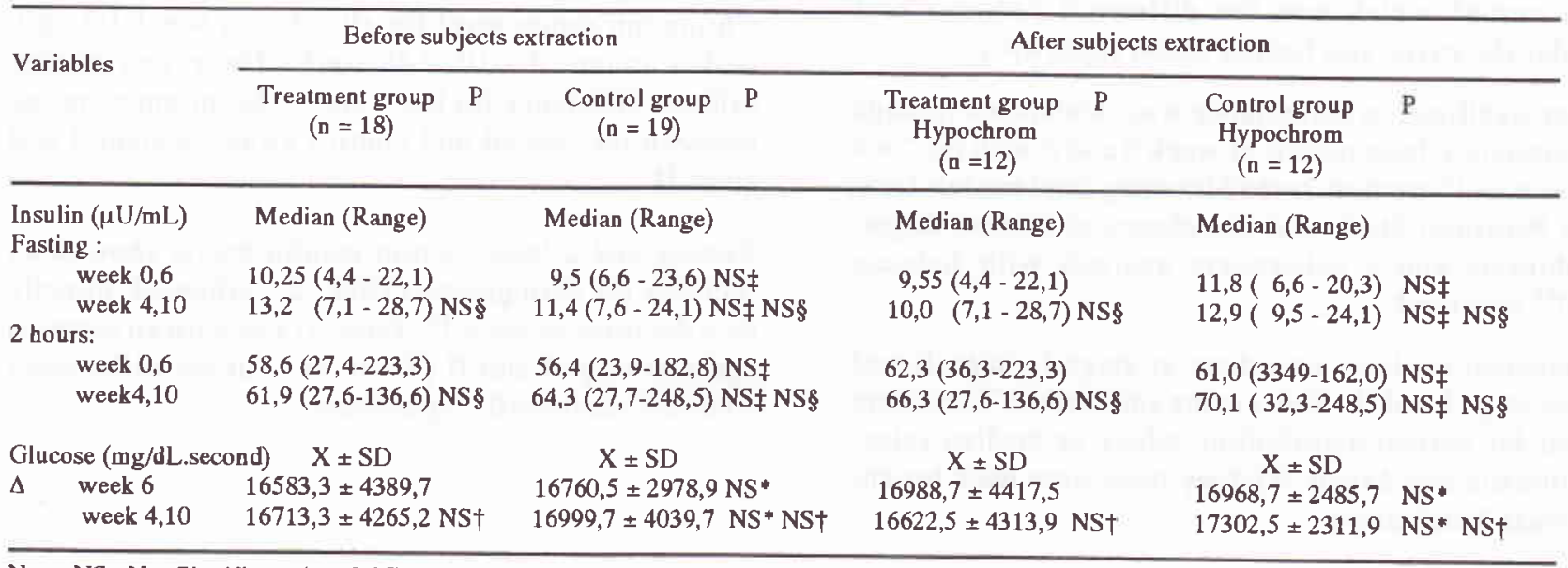

Note: NS : Not Significant $(p>0,05), *$ Independent $t$ test, $\uparrow:$ Dependent t test, $¥:$ Mann Whitney test, $\S:$ Wilcoxon test

Some investigators reported that suplemental $\mathrm{Cr}$ was more beneficial in NIDDM subjects with low level of body $\mathrm{Cr}^{23,24}$ With a cut off point of $0.14 \mu \mathrm{g} / \mathrm{L} \mathrm{Cr}$ serum (WHO, 1996), an extraction of hypochromic subjects $(<0,14 \mu \mathrm{g} / \mathrm{L}$ Cr serum) was done in this study to see whether it gave the same results. Statistical analysis on hypochromic subjects from the treatment and control group showed no significant differences (Table 2,3,4).

The same results were seen for blood sugar levels. With regard to blood sugar control, there was no significant difference between the treatment and control group at stage I (Table 2) and stage II (Tabel 3 ) even when the hypochromic subjects were extracted.

Overall analysis for both stage I and II showed a different outcome. Increase in the $\Delta$ area under the curve which was seen in both groups was directly followed by a decrease in the hypochromic subjects from the treatment group and an increase in the hypochromic subjects of the control, even though this was still not statistically significant. Above datas showed that $500 \mu \mathrm{g} \mathrm{Cr}$ picolinate daily as a supplementation for 4 weeks in NIDDM subjects did not control serum insulin and blood sugar better than without.

\section{DISCUSSION}

\section{Body Chromium}

Serum $\mathrm{Cr}$ levels in this study showed the same results in NIDDM patients as reported by Morris which was $60 \%$ of the normal subjects. ${ }^{12}$ In this study, the effect of $\mathrm{Cr}$ supplementation on relative chromium response was not seen in the treatment group as well as control.
The very low serum $\mathrm{Cr}$ levels and the still not clearly known $\mathrm{Cr}$ metabolism made this fact difficult to explain. This might be linked to the fact that there was still a very small number of studies done on hyperglycemic and diabetic subjects in connection with body $\mathrm{Cr}$ levels.

\section{Serum Insulin}

Improvement in insulin levels which was statistically significant was reported by Anderson using $500 \mathrm{~g} \mathrm{Cr}$ picolinate twice daily for 2 - 4 months in 60 NIDDM subjects. ${ }^{24}$

In this study the change in serum insulin level 2 hours after glucose loading was inconsistent although overall it has been shown to be beneficial to the treatment group. In stage I (Table 2) both groups showed an increase in serum insulin i.e., the control group: $25 \%$ and the treatment group: $21 \%$, whereas in stage II (Table 3) decrease of serum insulin in the treatment group (11\%) was bigger than control $(7 \%)$. The combined analysis of both stage I and II (Table 4) showed that the increase in the control group (14\%) was bigger than the treatment group (5\%). Nevertheless, all the findings were not statistically significant. It seems that the dosage of $\mathrm{Cr}$, length of treatment and the number of subject made these results different from Anderson's study.

\section{Blood Glucose}

Improvement in glucose tolerance was first reported by Glinsmann and Mertz in 3 out of 6 NIDDM subjects who were given $180-1000 \mathrm{~g} \mathrm{Cr}$ chloride for $15-120$ 
days. ${ }^{15}$ Some results was found by Levine in 4 out of 10 diabetic subjects given $150 \mu \mathrm{g} /$ daily for 4 months. ${ }^{25}$ On the other hand, other investigators reported no improvement in blood glucose after $\mathrm{Cr}$ supplementation. $^{26,27}$

In this study the blood sugar control showed inconsistent result. Decrease in stage I (Table 2) was followed by an increase in stage II (Table 3 ). This might be connected in some way to the individual variety of the subjects especially with regard to their diet. The quantity of food intake between the treatment group in stage I which became the control group in stage II showed an increase of carbohydrate intake $(20 \%)$ although these findings were not statistically significant.

Analysis on both stage I and II which earlier showed an increase in the " $\Delta$ area under the curve" in both groups, after extraction was soon followed by a decrease in the hypochromic treatment subjects and an increase in the hypochromic control subjects (Table 4). It seems that $\mathrm{Cr}$ supplementation was more beneficial to the diabetic subjects with low serum Cr levels although this was not statistically significant.

\section{CONCLUSION}

After statistical analysis, findings in this study showed that supplemental $\mathrm{Cr}$ picolinate $500 \mu \mathrm{g} /$ daily for 4 weeks in NIDDM subjects does affect serum insulin levels and blood sugar control.

A bigger number of subjects with a longer period of treatment, using larger doses of $\mathrm{Cr}$ (800-1000 $\mu \mathrm{g} / \mathrm{daily}$ ) might be needed to determine this matter further.

\section{REFERENCES}

1. Pi-Sunyer FX, Offenbacher EG. Chromium. In: Present Knowledge in Nutrition (Olson R.E., ed.) vol. 2, 5th ed., The Nutrition Foundation, Washington DC. 1984: 571-86.

2. Committee on Diet and Health, Food and Nutrition Board Trace elements. National Academy of Sciences, Washington DC. 1989: 381-2.

3. Czajka Narins DM. Minerals. In Krause's Food, Nutrition and Diet Therapy (Mahan LK, Arlin MT). 8th ed. W.B. Saunders Company, Philadelphia. 1992: 131-2.

4. Nielsen FH. Chromium. In Modern Nutrition in Health and Disease. 8th ed. Lea \& Febiger. A Waverly Company. 1994; 1: 264 - 8 .

5. Anderson RA, Kozlovsky AS. Chromium intake, aborption and exretion of subjects consuming self selected diets. Am J Clin Nutr 1985; 41: 1177-83.

6. National Research Council. Recommended Dietary Allowances. 10th ed. National Academy Press, Washington DC. $1989 ; 241-3$.
7. Schroeder HL. The role of chromium in mammalian nutrition. Am J Clin Nutr 1968; 21: 230 - 44.

8. Stoecker BJ. Chromium. In: Present Knowledge in Nutrition (Brown ML. ed), 6th ed. Nutrition Foundation, Washington DC. 1990: 287-91.

9. Offenbacher EG, Pi-Sunyer FX, Rinko CJ. Rapid enzymatic pretreatment of samples before determining chromium in serum or plasma. Clin Chem 1986; 32: 1383-6.

10. WHO. Chromium. In: Trace elements in human nutrition and health. 1996: 155 - 9.

11. Solomon NW. Chromium dalam Parenteral Micro-nutrition (Baumgartner TG, ed). 2nd ed. Fujisawa, USA. 1991: 253 -61 .

12. Morris BW, Griffiths H, Kemp GJ. Correlations between abnormalities in chromium and glucose metabolism in a group of diabetics. Clin Chem 1988; 34: 1525-6.

13. Jeejeebhoy KN, Chu RC, Marliss EB, et al. Chromium deficiency, glucose intolerance, and neuropathy reversed by chromium supplementation, in a patient receiving long term total parenteral nutrition. Am J Clin Nutr. 1977; 30: 531-8.

14. Anderson RA, Polansky MM, Bryden NA, Canary JJ. Supplemental chromium effects on glucose, insulin, glucagon and urinary chromium losses in subject consuming controlled low chromium diets. Am J Clin Nutr 1991; 154: 909-16.

15. Glinsmann WH, Mertz W. Effect of trivalent chromium on glucose tolerance. In: Metab Clin $\operatorname{Exp} 1966 ; 15:$ 510-20.

16. Uusitupa MIJ, Kiempulainen JT, Voutilainen E, et.al. Effect of oral chroium supplementation in glucose tolerance, insulin response, and serum lipids in non insulin dependent diabetics. Am J Clin Nutr 1983; 38: 404-10.

17. Waspadji S. Penelitian Diabetes Melitus - Suatu tinjauan tentang hasil penelitian dan kebutuhan penelitian masa yang akan datang. Acta Med Indones 1988; XX: 87-98.

18. Offenbacher EG. Metabolic chromium balances in man. Am J Clin Nutr 1986; 44: 77-82.

19. Konsensus Pengelolaan Diabetes Melitus di Indonesia. 1993.

20. Badan Tenaga Atom Nasional. Pusat Aplikasi Isotop dan Radiasi Laboratorium Radiokimia Bidang Kimia dan Biologi. Analisis Pengaktifan Neutron, Jakarta. 1996.

21. Liu VJK, Morris JS. Relative chromium response as an indicator of chromium status. Am J Clin Nutr 1978; 31: 972-6.

22. Nelson M. INDONAP-Indonesian Foods Nutrient Analysis Programme. Version 2.0. Kings College London. 1995.

23. Abraham AS, Brooks BA, Eylath U. The effects of chromium suplementation on serum glucose and lipids in patients with and without non-insulin dependent diabetes. Metabolism 1992; 41: 768-71.

24. Anderson RA. Trace metal supplements lower blood glucose and improve insulin levels. Asian Medical News, September ed. (abstract). 1996.

25. Levine RA, Stretchten DHP, Doisy RJ. Effects of oral chromium supplementation on the glucose tolerance of elderly human subjects. Metabolism 1968; 17: 114-25.

26. Sherman L, Glennon JA, Breck WJ. Failure of trivalent chromium to improve hyperglycaemia in diabetes mellitus. Metabolism 1968; 17: 439-42.

27. Wise A. Chromium supplementation and diabetes. Jama 1978; 240: 2045-6. 